\title{
The Christian's Political Responsibility According to the New Testament*
}

\section{C.E.B. Cranfield}

The New Testament contains a very considerable amount of material bearing on the political responsibility of the Christian-much more, I think, than someone who has not yet questioned it seriously on the subject would be likely to expect. It will, therefore, be wise for us, before attempting to draw out the New Testament teaching, to try to get a general idea of the various ranges of material which ought to be taken into account.

These may be very roughly indicated as follows:

(i) Passages containing direct exhortation on the subject. These are the passages which first come to mind when the subject is mentioned: Mark 12:1317 (= Matt. 22:15-22 = Luke 20:20-26); Romans 13:1-7; 1 Timothy 2:1-7; Titus $3: 1-2 ; 1$ Peter 2:13-17.

(ii) Passages which, while not containing exhortation on the subject, have some sort of reference to the state. This range of material may be subdivided into (a) passages which throw light on the attitude of Jesus to the state: e.g. Mark 10:42 (= Matt. 20:25 = Luke 22:25-the saying about the Gentile rulers' lording it over their subjects); Luke 13:32 (our Lord's reference to Herod as 'that fox'); Mark 13:9 (= Matt. 10:18 = Luke 21:12-13-the reference to standing before governors and kings for Christ's sake); (b) the Passion narratives; (c) the Birth narratives; (d) passages which throw light on Paul's attitude to the state: e.g., 1 Corinthians 2:6-8 (the reference to the rulers of this world being ignorant of the divine wisdom which he teaches); 1 Corinthians $6: 1$ 6 (the warning against taking a dispute with a fellow-Christian before a heathen court); Acts 16:19-39 (the account of Paul's imprisonment at Philippi and his insistence that the magistrates should come in person to release him); and the last chapters of Acts from 21:31 onwards; (e) Revelation 13 (the passage about the beast from the abyss).

(iii) Passages which, while not referring to, yet have an important bearing upon, the state and the Christian's political responsibility. These may be subdivided into (a) passages dealing with the rule of the exalted Christ; (b)

* The Bible and Christian Life (Edinburgh: 1985), 48-68. Reprinted by kind permission of $T$. and T. Clark, Edinburgh. Biblical quotations are from the English Revised Version. 
passages concerned with eschatology; (c) passages which make clear the reality and universality of $\sin$; (d) passages which reveal to us in our fellow-man 'the brother for whose sake Christ died'; (e) passages containing ethical teaching, especially those which are concerned with love to one's neighbor; and perhaps we should add (f) passages concerning the law.

The above survey is by no means exhaustive, but it is enough to show that there is no lack of New Testament material relevant to our subject. It should also have made it clear that, while the passages mentioned under (i) are of very great importance for our present purpose, it would be extremely foolish to try to build up a New Testament doctrine of the Christian's political responsibility upon them exclusively. This has sometimes been attempted in the past-with calamitous results. The passages under (i) will certainly be misinterpreted, if they are interpreted in isolation from the material indicated under (ii) and (iii).

The first thing to be noticed about the New Testament material is that all the passages which were mentioned under (i) in our preliminary survey agree that the Christian has a political responsibility which is inescapable, has an obligation toward the state. Thus in Mark 12:13-17, whereas the Pharisees and Herodians in their question use the simple verb "give" ("Is it lawful to give tribute unto Caesar, or not?"), Jesus in his reply uses the compound verb $\dot{\alpha} \pi \sigma_{i} \delta \delta o ́ \nu \alpha \iota$ (RV: "render"), which means "to give or pay back something which one owes as a debt," thereby indicating that they are under an obligation to Caesar. In Romans 13:1-7 the subject of the imperative $\dot{v} \pi$ or $\alpha \sigma \sigma \epsilon \sigma \theta \omega$ is $\pi \hat{\alpha} \sigma \alpha$ $\psi v \chi \eta \dot{~(" e v e r y ~ s o u l, " ~ i . e ., ~ i n ~ t h i s ~ c o n t e x t ~ " e v e r y ~ C h r i s t i a n ") . ~ P a u l ~ i s ~ i n d i c a t i n g ~}$ emphatically that there is no one in the church who is exempted from the duty to "be in subjection to the higher powers." In 1 Timothy 2:1-7 prayers "for all men; for kings and all that are in high place" are that to which the writer exhorts ( $\pi \alpha \rho \alpha \kappa \alpha \lambda \hat{\omega}$-the regular word for Christian exhortation that is based on the gospel) "first of all." The same assumption is to be seen in Titus 3:1-2 and 1 Peter 2:13-17. Common to all these passages is the conviction that every Christian has an inescapable obligation toward the state.

\section{II}

In the second place, we have to ask, What reasons for the Christian's political responsibility are indicated in the New Testament either explicitly or implicitly? Why, according to the New Testament, has the Christian a duty toward the state? A number of reasons may be distinguished:

(i) Once more we begin with Mark 12:13-17. It is important here to remember the occasional nature of the teaching it contains. While the saying of 
Jesus which forms the climax of the section has far-reaching significance, its shape is to a considerable extent determined by the question which has been put to him-by its limited reference (it is not a general question about the citizen's duty to the state, but one specifically concerned with the matter of the tribute) and also by the fact that it is not motivated by a sincere desire for guidance but is a deliberate attempt on the part of our Lord's enemies to trap him. They knew that, if he answered "Yes" to their question, his popularity with the mass of the people would be at an end, while, if he said "No," they could at once denounce him to the Romans. But Jesus' response is not just a skilful evasive action; it is also, as the early church clearly realized, a piece of teaching of abiding and general significance. Jesus asks his questioners to show him a denarius, not because he does not know what is on it, but because he wishes to show up their hypocrisy and also because the fact that they are actually using Caesar's coins is an essential element of the situation. Those who are taking advantage of the amenities provided by Caesar's rule are under a moral obligation to make some payment in return. One reason, then, why the Christian has a duty to the state is that he is a beneficiary of it.

(ii) Another, and a more theological, reason is indicated in Romans 13:1b

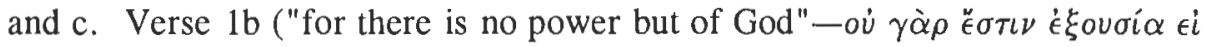
$\mu \grave{\eta} \dot{u} \pi \grave{o} \theta \epsilon o \hat{u}$ ) expresses a truth already familiar to the Jews (cf. Jer. 27:5f.; Dan. $2: 21,37 f$.; $4: 17$ (cf. $4: 25,32 ; 5: 21$ ); Wisd. $6: 3 ; 1$ Enoch $46: 5$ ), namely, that it is God who sets up (and overthrows) rulers, and that no one actually exercises ruling authority unless God has set him up. Verse 1c ("and the powers that be

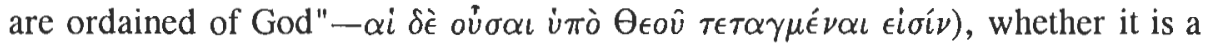
general statement or, as is perhaps more likely, a particular statement about the actual authorities with which both Paul and the church in Rome had to do, namely, the Roman Emperor and his representatives, is a corollary of verse 1b. Verse 2 draws out the implications of verse $1 \mathrm{~b}$ : to fail-to-be-subject $(\dot{\alpha} \nu \tau \iota \tau \dot{\alpha} \sigma \sigma \epsilon \sigma \theta \alpha \iota)$ to the authority is rebellion against God's ordinance, and, as such, will not go unpunished by God.

(iii) A third reason is indicated in Romans 13:3f. ("For rulers are not a terror to the good work, but to the evil. And wouldest thou have no fear of the power? do that which is good, and thou shalt have praise from the same: for he is a minister of God to thee for good. But if thou do that which is evil, be afraid; for he beareth not the sword in vain: for he is a minister of God, an avenger for wrath to him that doeth evil"). I have argued elsewhere ${ }^{1}$ that Paul in these verses is neither just thinking of his own good experiences at the hands of the imperial government nor just speaking ideally, but means that, consciously or unconsciously, willingly or unwillingly, the authority will surely praise the good work and punish the evil, because it is, whether it knows it or not, whether willingly or unwillingly, God's servant appointed by God for the very purpose of helping Christians toward salvation and punishing those who do evil. 
(iv) 1 Timothy 2:1-7 indicates a reason which to some extent overlaps, but is not identical with, that given in Romans 13:3-4 which we have just considered. The Christian is to pray for those in authority, in order "that we may lead a tranquil and quiet life in all godliness and gravity. This," that passage continues, "is good and acceptable in the sight of God our Savior; who willeth that all men should be saved, and come to the knowledge of the truth. For there is one God, one mediator also between God and men, himself man, Christ Jesus, who gave himself a ransom for all . . ." It is implied that God wills the state as a means to promoting peace and quiet among human beings, and that God desires such peace and quiet because they are in some way conducive to human beings' salvation. It is God's purpose that the state should, by restraining the chaotic tendencies of human beings' self-assertion, maintain those outward conditions under which the gospel may be preached to all and sundry without hindrance. Thus the state is a provision of God's patience, which desires to give to all human beings the opportunity to repent and be saved; and we have to serve the state for the sake of our fellow human beings? eternal salvation. Our fulfillment of our political responsibility is therefore a necessary part of our fulfillment of our evangelistic responsibility.

(v) A fifth reason may be inferred from the fact that Romans 13:1-7 is part of the exhortation which begins at 12:1. The Roman Christians' subjection to the powers that be is part of the "reasonable service" or "understanding

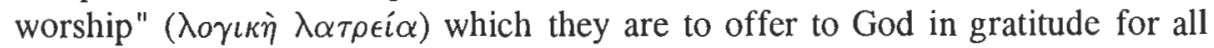
that he has done, is doing, and will do, for them in Jesus Christ.

(vi) The context of Romans 13:1-7 suggests a further reason. This passage is both preceded and followed by exhortations to love (12:9ff. and 13:8-10), and it is no erratic boulder in its context. Since the state serves both the ordinary temporal good of our fellow human beings and also their eternal salvation, the right service of the state is an integral part of our debt of love to our neighbors.

(vii) Finally, the fact that not only authority over the church but "all authority . . . in heaven and on earth" has been given to the exalted Christ (Matt. 28:18) and that he is "the ruler of the kings of the earth" (Rev. 1:5), the "Lord of lords, and King of kings" (Rev. 17:14; cf. 19:16), is a compelling reason why the Christian should view the state and his or her responsibility to, and for, it with the greatest seriousness. The Christian knows that it is an instrument of Christ's kingly rule.

\section{III}

In the third place, we have to ask about the content of the Christian's political responsibility. What, according to the New Testament, does the Christian owe the state? What is the content of the subjection enjoined in Romans 13:1; Titus 3:1; 1 Peter 2:13f.? 
It is often assumed that i $\pi \sigma \tau \alpha \sigma \sigma \epsilon \sigma \theta \alpha t$ in these passages simply means "obey." Thus Sanday and Headlam entitled the section Romans 13:1-7 "On Obedience to Rulers, " and stated in their introductory summary to it: "The civil power . . . must be obeyed. Obedience to it is a Christian duty . . ."; and, more recently, Professor Barrett in his commentary has used the phrase "obedience to magistrates." But, as I tried to show in the article to which I have already referred, $\dot{v} \pi \circ \tau \alpha \dot{\alpha} \sigma \sigma \epsilon \sigma \theta \alpha$ does not always mean "obey." This meaning is excluded in Ephesians 5:21; for here the word is used of a reciprocal obligation ("subjecting yourselves one to another in the fear of Christ"), and obedience cannot be reciprocal. Here it would seem to denote the recognition that one's fellow-Christian has, as Christ's representative to one, an infinitely greater claim on one than one has on oneself, and the behavior that flows from such a recognition. We may compare the expressions "in honor preferring one another" in Romans 12:10 and "each counting other better than (or "superior to") himself" in Philippians 2:3. It is therefore not unreasonable to maintain that in Romans 13:1; Titus $3: 1 ; 1$ Peter 2:13f., the word $\dot{u} \pi o \tau \dot{\alpha} \sigma \sigma \in \sigma \theta \alpha \iota$ denotes not an uncritical obedience to the authority's every command but the recognition that one has been placed below the authority by God and that, as God's servant and the instrument of Christ's kingly rule, it has a greater claim on one than one has on oneself, and such responsible conduct in relation to the authority as results from such a recognition.

The rightness of this interpretation reached by way of a philological inquiry is borne out by the fact that the New Testament contains a considerable amount of material which clearly implies that a Christian does not owe the civil government an unquestioning obedience. We may think of Mark 12:17, where Jesus' words "and unto God the things that are God's" indicate plainly that there are limits to what is owed to Caesar. We may think also of much of the material mentioned in categories (ii) and (iii) in our preliminary survey. For example, our Lord's reference to Herod Antipas as "that fox" (Luke 13:32) hardly suggests that his attitude to his lawful ruler was one of unquestioning, uncritical obedience; and, according to Acts 16:35ff., Paul himself did not depart meekly at the behest of the magistrates of Philippi but rather sought to recall them to a proper sense of their own true dignity by insisting on their coming in person to release him and Silas. It is hardly necessary to mention Revelation 13 and 14, where it is certainly not implied that Christians should docilely worship the beast or receive the mark of his name. That, whenever the civil ruler's commands conflict with the commandments of God, the Christian "must obey God rather than men" (Acts 5:29) is in the New Testament everywhere presupposed. In view of the New Testament material generally we may say that the subjection to the authority which is enjoined, while it will often include obedience, is never simply obedience and nothing more, is never an 
uncritical, unquestioning obedience, and in some circumstances will not include obedience at all.

Having dealt with the common fallacy that St. Paul enjoined obedience to magistrates simpliciter (a misunderstanding which has had many exponents and often calamitous results but which would never have arisen, if Christians had resisted the temptation to expound a particular passage of the New Testament independently of the rest of it), we must now attempt to discover what elements are (according to the New Testament) comprised in the subjection or $\dot{v} \pi o \tau \dot{\alpha} \sigma \sigma \epsilon \sigma \theta \alpha \iota$ which the Christian owes the powers that be.

We list, first, six things which the Christian owes the powers that be in the circumstances actually envisaged by the New Testament writers, namely, in an authoritarian state. All of these are equally obligatory for the Christian citizen of a modern democracy.

(i) Respect $(\tau \iota \mu \eta \dot{\eta})$. Thus Romans 13:7 enjoins, "Render to all their dues: ... honor to whom honor"; and 1 Peter 2:17, "Honor the king." To respect the government and its various agents means taking them seriously. It means taking them thoroughly seriously - usually much more seriously than they take

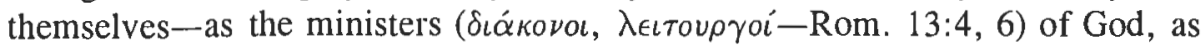
men who have been ordained by God (Rom. 13:1) and are accountable to him for the solemn trust which he has committed to them and therefore have a high and reverend dignity. It will often mean treating with full seriousness for the sake of their office men who themselves have little or no understanding of the true dignity of their office and who in themselves are contemptible. But it certainly does not mean flattery or "respect of persons"; indeed these are incompatible with a proper respect. Nor does it forbid one to claim whatever legal rights one has over against the government. Paul was not showing disrespect for the magistrates at Philippi, but was rather paying them true respect, when he insisted on his legal rights and thereby summoned them to a proper sense of their own dignity (Acts 16:35ff.). And, when rulers or their agents behave unworthily and commit injustice, respect will involve, for those whose position makes it possible, administering rebuke. We may cite John the Baptist's rebuking of Herod (Mark 6:18; Luke 3:19), concerning which Calvin comments: "Hence we learn with what unshaken fortitude the servants of God ought to be armed when they have to do with princes; for in almost every court hypocrisy and servile flattery are prevalent; and the ears of princes, having been accustomed to this smooth language, do not tolerate any voice which reproves their vices with any severity" and "John has thus, by his example, furnished an undoubted rule for pious teachers, not to wink at the faults of princes, so as to purchase their favor at this price, how advantageous soever that favor might appear to be to the public interests."

(ii) Obedience so far as it does not involve disobeying God. While it is of the greatest importance to realize that i $\pi \sigma \tau \alpha \dot{\alpha} \sigma \sigma \sigma \theta \alpha \iota$ does not simply mean 
"obey" and in some circumstances will not involve obedience at all, it is certainly true that $\dot{\tau} \pi \sigma \tau \dot{\alpha} \sigma \sigma \epsilon \sigma \theta \alpha \iota$ will usually involve obedience. In Titus $3: 1$ the words "to be in subjection to rulers, to authorities" are followed by "to be obedient" ( $\pi \epsilon \iota \theta \alpha \rho \chi \epsilon \hat{\imath} \nu)$. The Christian is under obligation to obey the government of the state of which he is a citizen, its various agents, and the duly enacted laws of the state, in so far as such obedience does not conflict with obedience to God.

(iii) $A$ serious and responsible disobedience, whenever obedience would involve disobeying God. We may refer to Acts 4:19f. ("But Peter and John answered and said unto them [that is, to the Sanhedrin], Whether it be right in the sight of God to hearken unto you rather than unto God, judge ye: for we cannot but speak the things which we saw and heard") and 5:29 ("But Peter and the apostles answered and said, We must obey God rather than men").

(iv) Payment of taxes. The basic text here is, of course, Mark 12:13-17 (= Matt. 22:15-22 = Luke 20:20-26) (The Question about Tribute to Caesar). Compare Romans 13:6f. ("For for this cause ye pay tribute also; for they are ministers of God's service, attending continually upon this very thing. Render to all their dues: tribute to whom tribute is due; custom to whom custom;

"). The Christian is under obligation to pay his dues to the state, because, as a beneficiary of it, he owes it some payment in return for the protection and amenities which it provides, and because no state can function without resources, and therefore a fundamental refusal to pay taxes would be a fundamental "No" to the state as such. We do not exclude the possibility that it might in certain circumstances be right to refuse to pay a particular tax.

(v) Prayer for those in authority. Thus 1 Timothy 2:1ff.: "I exhort therefore, first of all, that supplications, prayers, intercessions, thanksgivings, be made for all men; for kings and all that are in high place; that we may lead a tranquil and quiet life in all godliness and gravity. This is good and acceptable in the sight of God our Savior; who willeth that all men should be saved, and come to the knowledge of the truth." This prayer, earnest, persevering and believing, for the civil authority is an essential part of the debt which the Christian owes it, whether it is Christian or pagan, religiously indifferent or antireligious, just or unjust.

(vi) Witness to Christ. An essential part of the Christian's debt to the powers that be is that he should not fail to bear witness to Christ in word and deed and to play his part in the corporate witness of the church within the state of which he is a citizen, a witness which has to be borne by preaching and sacrament, by the church's order and common life, and by its service of the community. Very often this witness will entail suffering, and sometimes death. "Take ye heed to yourselves," says Jesus, "for they shall deliver you up to councils; and in synagogues shall ye be beaten; and before governors and kings shall ye stand for my sake, for a testimony unto them" (Mark 13:9). This is 
indeed the most essential service which the Christian owes the government and its agents; for by it he attests their real dignity as ministers of God, servants of Christ's kingly rule, the limits of their authority, and also the promise under which they stand.

We have now, I think, listed all the elements of the Christian's subjection to the powers that be, which are actually specified in the New Testament. But the New Testament writers envisaged an authoritarian state, in which there was no question of the ordinary citizen's sharing responsibly in government. We have therefore to translate what they say into terms of our different political order, if we are to apply it to ourselves without serious distortion. It is clear from what has been set out above that according to the New Testament the Christian living under an authoritarian system is under obligation to do what he can for the maintenance of the state as a just state. The Christian living in a democracy can do much more for the maintenance of the state as a just state. It is therefore surely a true drawing-out of the New Testament teaching to assert that the extra which the Christian living in a democracy can do for the maintenance of the state as a just state is obligatory for him, is an essential part of his proper subjection to the powers that be, and that for him to fail to render this extra would be to resist the power and so be guilty of rebellion against the ordinance of God (Rom. 13:2) just as much as to fail to fulfill obligations (i) to (vi) above would be.

So we go on to list four additional obligations which are necessary elements of a Christian's subjection in a democratic state.

(vii) Responsible participation in local, state, and national elections, in the fear of Christ and in love to one's neighbor. In normal circumstances to fail to register one's vote is to abandon one's share of responsibility for the maintenance of the state as a just state and therefore a dereliction of one's duty as a Christian. We should, however, allow for the possibility of exceptional circumstances arising, in which the only possibility open to a Christian might be to abstain from voting.

(viii) A serious and sustained attempt to keep oneself as fully and reliably informed as possible concerning political issues-since responsible voting in the fear of Christ and in love to one's neighbor is only possible on the basis of adequate knowledge. This will naturally involve a diligent reading of newspapers, and, unless we are going to read all the available papers, it will be important to choose some at least of those we are going to read for their reliability and not for less important reasons. Here obligations will vary according to the particular Christian's intellectual ability and education. Upon those who know that God has given them a more than average intellectual ability and who have had the advantage of a good education there rests a special responsibility in this matter. They may well often feel obliged to go farther 
afield than the newspaper and read books of background information and such things as reports of presidential or congressional commissions.

(ix) Criticism of the government, its policies and its agents, in the light of the gospel and law of God. We have seen that even in an authoritarian state the Christian never owes the government an uncritical, unquestioning obedience. In a democracy, where the citizen's active cooperation is required and the scope of criticism is so much greater, the Christian owes the government in power a continuing criticism in the light of the Word of God. But, if one is to fulfill such an obligation, one will need not only the knowledge referred to under (viii) above, but also a real knowledge of Holy Scripture. One will not be able to render to the government the critical cooperation which one owes, unless one is a mature Christian who is ever striving oneself to hear God's Word.

(x) Something which overlaps (ix) to some extent, but is not identical with it-an unceasing, untiring endeavor to support just and humane policies and to oppose those policies and particular decisions which are unjust or inhumane, by helping to build up an enlightened public opinion and in the various other ways (besides voting in elections) which are constitutionally open to one. The methods to be adopted will vary according to the situation and one's own personal circumstances. The obvious possibilities include such things as personal conversations, writing letters to the appropriate members of the administration and the Congress, and to the press, joining a political party (or resigning from one), canvassing in elections, organizing or attending mass meetings and demonstrations.

At this point it is, I think, probably right to list as a distinct element of the Christian's service of the state, whether under an authoritarian or a democratic system, something which, while it is not explicitly mentioned in the New Testament as a part of the Christian's obligation to the powers that be, is very obvious, has already been hinted at several times in this paper, and may be said to be the primary service owed by the Christian to the state, the service upon which the faithful rendering of all the other services depends, namely-

(xi) A sustained endeavor to be a mature Christian, so transformed by the renewing of one's mind as to be able to "prove what is the good and acceptable and perfect will of God." The first and fundamental service which the Christian owes the government and its agents is that one should oneself be "swift to hear" the Word of God, allowing oneself to be continually engaged in conversation by the Lord of the church through the medium of the written words of the Bible.

We must now mention two possible further elements of the subjection owed by the Christian, both of which are highly controversial. Each of them would require much more than a whole paper to itself for an adequate discussion. All I shall do is to indicate as briefly as possible my own present provisional opinion. 
(xii) Readiness, in certain circumstances and within certain limits, to join in military action at the command of the government. The New Testament nowhere gives a direct answer to the question which has tormented so many in recent years, "Should a Christian refuse to take part in military action?" This is not really surprising, since in the first century A.D. Jews were exempt from military service, and the Roman authorities, while they had the right to conscript non-Jewish males, seldom had any need to do so, there being generally an adequate supply of volunteers. We have therefore to try to discover what answer is implicit, and this is notoriously difficult. To state baldly my own opinion-it seems to me, so far as I can see at present, that the fact that the New Testament clearly affirms the state as a divine provision for men implies that its answer cannot be an absolute "No"; for an absolute "No" at this point is surely a "No" to the institution of the state as such in the circumstances of this world as we know it. Paul himself seems in Romans 13:4 to be assuming that being in a position to use force is an integral part of the state's functioning. But I certainly do not think that there is any basis in the New Testament for the notion, common in the post-Constantinian church, that war is a normal activity of a state which is to be accepted quite complacently, or for the assumption of the thirty-seventh Article of the Church of England that the mere fact that the government has decided to make war is in itself enough to make it lawful for the Christian to fight and kill. It seems to me very clear that the Christian is under obligation to refuse to participate in military action, if he is convinced either that it is being employed otherwise than in the last resort, or that it is being employed in an unjust cause. I should myself also have to say that I believe that there are some fairly clearly definable sorts of military action in which a Christian ought in no circumstances to be willing to take part. ${ }^{2}$

(xiii) Readiness in certain extreme circumstances to engage in armed rebellion in order to overthrow a government that is intolerably unjust and to replace $i t$. Here again the New Testament gives us no direct guidance. Neither our Lord's attitude to the Zealots nor Romans 13:2 settles the matter. It does not follow from the fact that our Lord was opposed to the advocates of revolt against Rome that he would necessarily have discountenanced on principle rebellion in all conceivable circumstances. It is easy enough to think of very good reasons for disapproving of such would-be revolutionaries against Rome, quite apart from any disapproval of rebellion on principle. For one thing, the Roman government was certainly not so generally unjust as to warrant rebellion; for another, these fanatical advocates of revolution were not merely thinking in terms of establishing a more just state but actually thinking to establish the kingdom of God; and, thirdly, it was obvious to the reasonably farseeing that revolt would be hopeless. With regard to Romans 13:2, we should have to ask whether it is not possible for a government to be so unjust and so full of disorder as to cease to have any claim to be regarded as an "authority" ( $\dot{\epsilon} \xi$ ovoi $\alpha$, 
RV: "power") in the sense of Romans 13:1 and 2, and whether a true and serious respect for God's ordinance may not in such extreme circumstances actually entail readiness to use force to overthrow a government that has become the direct opposite of what a government should be. For myself I cannot disapprove of those Christians in Germany who were involved in the attempt on Hitler's life in July 1944, and I am inclined to think that the Christian would be failing to take his government absolutely seriously-and so failing to render it the subjection which the New Testament enjoins-if, in the last resort, he were not ready even to use force against it, should it ever degenerate into mere tyranny. ${ }^{3}$

\section{IV}

In the fourth place, and finally, we ask, What guidance does the New Testament offer concerning the spirit, the frame of mind, in which the Christian ought to try to fulfill his political responsibility? It seems to me that there are at any rate three things to be said here.

(i) The Christian must, according to the New Testament, seek to fulfill his or her political responsibility in all seriousness and earnestness, as an obligation laid upon one by God and therefore inescapable, as a necessary part of one's obedience to Jesus Christ, of one's debt of love to one's neighbor, of one's evangelistic responsibility, a necessary part of that intelligent worship which one owes to God in gratitude for his mercy and goodness in Jesus Christ-in fact, because of all the things listed under II above. One's right to think of it as in any way an optional extra, in which one may or may not take an interest according to one's personal temperament and inclination, is most decisively and emphatically denied.

(ii) The Christian must seek to fulfill it in sobriety and realism. Under this heading there is a great deal to be said; but we only have time to mention a few points.

(a) The eschatological teaching of the New Testament makes clear the temporary nature of the state, and so warns against all absolutizing of it.

(b) The eschatological teaching of the New Testament makes it clear that we cannot establish the kingdom of God by our political (or, for that matter, by our ecclesiastical) actions, and so forbids "zealotism" with its inherent tendencies to fanaticism and ruthlessness.

(c) The New Testament's disclosure of the grim reality of sin, of the fact that all men without exception are sinners, and that even the Christian remains a sinner until he dies, opens the way to a realistic apprehension of the human situation with which politics have to do. We have an instance of such proper realism in our Lord's words recorded in Mark 10:42: "Ye know that they which are accounted to rule over the Gentiles lord it over them; and their great ones exercise authority over them." The RV unfortunately conceals the fact that the 
two Greek words compounded with $\kappa \alpha \tau \alpha$-which are used here (RV: "lord it over" and "exercise authority over") denote the exercise of lordship and authority over people to one's own advantage and their disadvantage, in other words, the exploitation of those over whom one has power. The Christian must, in the light of the New Testament, reckon constantly with the fact that every member of the government, every official, and every member of the electorate, in his own as in other countries, is a sinner. If he does so, he will be very much aware of the need at all times for safeguards designed to limit as much as possible the abuse of power, the need to scrutinize very carefully the claims and promises of politicians, the need to look beyond all high-sounding slogans to see how far they are but a mask disguising selfish purposes; and he will not be a party to any policy which involves handing over to any section of a community absolute power over the lives and destinies of another section.

(d) Both New Testament eschatology and the New Testament insistence on the fact of human sinfulness lead us to the realization that there are limits to what we can achieve in the sphere of politics, and that therefore limited goals are not to be despised. Often the only choice open to the Christian in a particular situation will be a choice between evils; but he will realize that it is not a matter of indifference whether the greatest possible, or the least possible, evil comes to pass, and that to help to bring about the greatest evil by refusing, out of a mistaken perfectionism, to choose the least is surely to be guilty of dereliction of duty. The Christian should be aware of the danger of being so preoccupied with the quest of the unattainable that one fails to achieve the limited goals which are within one's reach. Christian realism should enable us to see that, while it is not given to us to establish a perfect society within the course of history, to build in our time a society, which contains such a measure of justice and compassion as may make it, in spite of all its human imperfections and frailty, a recognizable pointer to the justice and compassion of God, is not beyond the bounds of possibility, and is a goal worthy of our untiring efforts.

(e) Included in this sobriety and realism are: the recognition that the purpose of civil government and of the state in God's intention is a purpose of mercy toward men ( 1 Tim. $2: 1 \mathrm{ff}$.), that is, toward individual men and women and children; the recognition that every human being, not only in one's own country but also throughout the whole world, is a brother or sister for whom Christ died (Rom. 14:15; 1 Cor. 8:11; 1 Tim. 2:6), and therefore someone of inestimable worth; the recognition that in each of those who are wretched and needy, wherever they may be, the exalted Christ is present to be honored or neglected (Matt. 25:40, 45). Holding fast these truths, the Christian will not be able to forget that the state exists for the sake of men and women and children, not they for the sake of the state, and he will possess in them a standard by which to measure policies and legislation. He will know that he must at all times and in all circumstances loyally abide by the principle that persons are 
infinitely more precious than property. He will, for instance, allow himself to be guided by it, when he has to weigh the relative importance of the various issues in a general election. He will be more concerned that the starving and undernourished throughout the world should have enough food than that his own countrymen should have more and more amenities; more concerned that the personal liberties and dignity of those who cannot defend themselves should be protected than that the income tax should be reduced. He will feel himself obliged to throw his weight on the side of generous and unselfish national policies, and in domestic affairs to take a special interest in the underprivileged, the misfits, and the lame dogs of society. He will know that human life is always to be reverenced. In time of war he will never forget that even the lives of the enemy are not cheap.

(iii) The Christian should fulfill his political responsibility in confidence and hope. (a) He knows that the state and civil authority are God's ordinance, that God has ordained them for a merciful purpose, and that he who has ordained them has not lost control over them. He knows that governments are God's ministers, who cannot help but serve him and further his gracious purposes, whether consciously or unconsciously, willingly or unwillingly, directly or indirectly. He is continually being reminded of one specially luminous instance, unique in its significance, that of Pontius Pilate, through whom, unworthy and unwilling servant though he was, God's perfect will for the redemption of mankind was accomplished. (b) The Christian knows that, when he passes from the ecclesiastical into the political sphere, he is not passing out of Christ's dominion into the dominion of some other lord, and that political affairs no less than the life of the church are within the dominion of Christ. He knows that the same Lord who is confessed and acknowledged by the church is also the Lord of the whole world, though not yet known as such by it. He knows that this Lord is already "the ruler of the kings of the earth" (Rev. 1:5), the "Lord of lords, and King of kings" (Rev. 17:14; 19:16), to whom "all authority hath been given ... in heaven and on earth" (Matt. 28:18), and that the governments of the nations are the servants of his royal rule. How then can he do otherwise than fulfill his political responsibility in confidence and hope? (c) The Christian knows too that the end toward which history moves is the coming in glory of Jesus Christ, the decisive and unambiguous manifestation of the kingdom of God, the establishment of God's new order. In that event he sees not only the ultimate limitation but also the ultimate promise under which the states and governments of history stand; for he knows that the time must come when it can be said: "The kingdom of the world is become the kingdom of our Lord, and of his Christ" (Rev. 11:15) and when at last "the nations shall walk amidst the light" of the "new Jerusalem," and "the kings of the earth . . . bring their glory into it" (Rev. 21:24). 


\section{ENDNOTES}

1. "Some observations on Romans 13:1-7," in NTS, 6 (1959-60), 176-192.

2. See K. Barth, Church Dogmatics, III/4, 55, 2, for an extremely valuable discussion of the question of war, pacifism, etc. [In 1983 I am bound to declare my conviction that the use of nuclear weapons, whether in a first strike or in retaliation, is, since it would necessarily be altogether indiscriminate, something which a Christian ought in no circumstances whatsoever to be willing to countenance.]

3. On the subject of armed rebellion see, in addition to the section of the Dogmatics cited above, K. Barth, The Knowledge of God and the Service of God (London: Hodder and Stoughton, 1938), 229-232. 